\title{
ANALISIS FINANSIAL PETERNAKAN SAPI PERAH RAKYAT DI KOTA TOMOHON (STUDI KASUS DIKELOMPOK RAMULU SANGKOR)
}

\author{
Ray Paksi Labodu*, Erwin Wantasen**,M.T. Massie ** dan Frangky N.S. Oroh ** \\ Fakultas Peternakan Universitas Sam Ratulangi, Manado 95115
}

\begin{abstract}
ABSTRAK
Penelitian inibertujuan untuk menganalisis kelayakan usaha ternak sapi perah"KelompokRamulu Sangkor" di KotaTomohon.Penelitianmenggunakan metode survey denganpendekatanstudi kasus. Sumber data yang diambil meliputi data primer dan data sekunder. Pengumpulan data dilakukan pada bulan Maret sampai April 2015. Analisis yang digunakan ialah analisis kriteria investasi yaittu $N P V, B C$ Ratio, IRR, ROI, dan analisis Keuntungan. Hasil penelitian bahwatotal biaya produksi usaha sapi perah sebesar Rp. 721.599.633/tahun-. dan penerimaan sebesar Rp. 951.217.667/tahun dari penjualan Susu, Kripik Susu, Eskrim, dan biogas. Berdasarkan hasil penelitian dapat disimpulkan usaha ternak Sapi Perah "Kelompok Ramulu Sangkor" secara finansial layak dijalankan dengan nilaiNPV Rp. 448.929.526, BC Ratio 2,880, IRR 50,05 , ROI 41,82 danKeuntungan sebesar Rp. 229.618.034 per tahun.
\end{abstract}

Kata Kunci :Sapi Perah, Finansial, Kelompok Peternak Ramulu Sangkor

\section{ABSTRACT}

FINANCIAL ANALYSIS OF DAIRY CATTLE FARM IN TOMOHON CITY (CASE STUDY AT THE RAMULU SANGKOR FARMER GROUP). Study was conducted to analyze feasibility of the Ramulu Sangkor farmer group in Tomohon city. Study was implemented using survey method in the case study of the farm. Data were taken directly to the

\footnotetext{
* Alumni Fakultas Peternakan

** Jurusan Sosial Ekonomi Fapet Unsrat
}

farmer as primary data and taken from related institution as secondary data. Survey was done for March to April 2015. Data were analyzed using infestation criteria analysis including $N P V, B C$ Ratio, $I R R, \quad R O I$ and profit analysis. Results showed that total investment were IDR 721.599.633/year and total receipt were IDR 951.217.667/year, of selling milk product and biogas. Therefore, it can be concluded that the Ramulu Sangkor farmer group was feasibly operated with NPV of IDR $448,929,526 .-$; BC Ratio of 2.880; IRR of 50.05 , ROI of 41.82 and profit value of IDR 229.618.034.- for one months.

Keywords: Dairy Cattle, Finance, Ramulu Sangkor Farmer Group

\section{PENDAHULUAN}

Pembangunan sub sektor peternakan sapi perahbertujuan untuk meningkatkan produksi susu menuju swasembada, memperluas kesempatan kerja dan meningkatkan pendapatan peternak.Peternakan sapi perah yang diusahakan oleh rakyat masih banyak menghadapi kendala antara lain kecilnya skala usaha karena lemahnya permodalan, rendahnya tingkat keterampilan peternak (Krisna dan Manshur, 2006). Usaha ternak sapi perah rakyat umumnya hanya 
dijadikan usaha sambilan selain bertani sebagai usaha utama. Petani akan menjual ternak tersebut jika mereka sewaktu-waktu membutuhkan biaya yang cukup besar (Priyono, 2008).

Menurut Arifin(2004) bahwa agribisnis berbasis peternakan adalah salah satu fenomena yang tumbuh pesat ketika lahan menjadi terbatas, karena sistim usaha tani memerlukan lahan yang besar namun ketersediaan lahan yang terbatas akan memicu efisiensi dan efektifitas penggunaan lahan tersebut. Oleh karena itu usaha peternakan sapi perah dapat di jadikan salah satu alternatif yang menjanjikan nilai keuntungan di masa depan.Produk susu merupakan produk pangan yang penting bagi kesehatan dikarenakan kandungan yang terdapat didalamnya. oleh karena itu usaha peternakan sapi perah perlu ditumbuh kembangkan karena mampu menjaga ketahanan pangan dan memberikan peluang usaha (Priyono, 2008).

Sejak tahun 2010 Populasi ternak Sapi Perah di Sulawesi Utara terus meningkat dari 37 ekor menjadi 216 ekor di tahun 2012 (Dirjen Peternakan RI, 2013). Optimalisasi potensi usaha sapi perah dapat diketahui antara lain melalui analisis finansial usaha dengan mengevaluasi investasi-investasi yang ditanamkan, biaya-biaya produksi dan penerimaan atas penjualan produk
(Kadariah, 2001).Potensi terbesar dalam usaha peternakan sapi perah saat ini terdapat di dalam usaha pemasarannya. Kondisi ini menjadi peluangusaha sapi perah kelompok Ramulu Sangkor dikota Tomohonberupa susu dan hasil olahannya seperti Eskrim, Kripik Susu serta kotoran dan hasil olahannya berupa gas. Kelompok Ramulu Sangkor menjalankan Usaha pengolahan susu berupa Kripik Susu, Eskrim, dan Biogas dari kotoran sapi. Usaha ini sudah dilakukan sejak tahun 2012 hingga sekarang ini namun demikian berapa besar keuntungan yang diperoleh dan kelayakan usaha sapi perah yang dilakukan kelompok Ramulu Sangkor belum diketahui sehingga masih membutuhkan kajian empiris.

\section{METODE PENELITIAN}

Penelitian ini dilakukan menggunakan metode survei dengan pendekatan studi kasus pada usaha ternak Sapi Perah jenis FH kelompok Ramulu Sangkor di Desa Kakaskasen II Kecamatan Tomohon Utara Kota Tomohon,Penelitian dilakukan dengan cara pengamatan dan wawancara langsung,dengan menggunakan daftar pertanyaan kepada pengurus kelompok Ramulu Sangkor. Data yang dikumpulkan adalah data primer yaitu biaya produksi, penjualan dan pendapatan usaha. Data sekunder diperoleh dari instansi/lembaga yang telah mengadakan pengumpulan data berkaitan dengan penelitian ini antara lain 
Dinas Pertanian, Peternakan dan Perkebunan Kota Tomohon, Dinas Pertanian dan Peternakan Provinsi Sulawesi Utara, Badan Pusat Statistik Sulawesi Utara, Badan Ketahana Pangan Sulawesi Utara, dan BMKG Kota Tomohon. Informasi lainnya diperoleh melalui Publikasi, Jurnal-jurnal penelitian yang telah ada baik melalui perpustakaan ataupun internet.

\section{HASIL DAN PEMBAHASAN}

Dari tabel 1. Dapat dilihat total biaya produksi pada usaha peternakan Sapi Perah kelompok Ramulu Sangkor dari pemeliharaan Sapi, Es krim, Kripik susu pada tahun 2012 sebesar Rp. 353.520.416, Pada tahun 2013 biaya produksi pemeliharaan Sapi, Es krim, Kripik susu, pembuatan digester Biogas sebesar Rp.782.723.116, Tahun 2014 total biaya dari pemeliharaan Sapi, Es krim, Kripik susu sebesar Rp. 1.028.555.366, Rata-rata total biaya dari tahun 2012 sampai 2014 sebesar Rp.721.599.633.

Total penerimaan dari Susu, Es krim, Kripik susu, pinjaman Bank, dan Biogas pada tahun 2012 sebesar Rp.271.900.000, Total penerimaan Susu, Eskrim, Kripik susu dan Biogas tahun 2013 sebesar Rp.915.040.000, dan total penerimaan pada tahun 2014 dari Susu, Es krim, Kripik susu sebesar Rp. 1.666.713.000. Rata-rata penerimaan dari tahun 2012 sampai 2014 sebesar Rp.951.217.667. Total keuntungan dari Susu, Es krim, Kripik susu dan pinjaman Bank pada tahun 2012 sebesar Rp.-81.620.416, Total keuntungan dari Susu, Es krim, Kripik susu, Biogas pada tahun 2013 sebesar Rp.132.317.284, dan total keuntungan ditahun 2014 dari olahan Susu, Es krim, Kripik susu dan pemanfatan feses menjadi Biogas sebesar Rp.638.157.634. Rata-rata keuntungan dari tahun 2012 sampai 2014 sebesar Rp.951.217.667.

Dari tabel 1. Dapat dilihat hasil analisis finansial usaha peternakan sapi perah kelompok Ramulu Sangkor. Nilai NPV dari usaha peternakan sapi perah kelompok Ramulu Sangkor dengan jumlah ternak 10 ekor pada tingkat diskon faktor $15 \%$ sebesar Rp.448.929.526. Nilai NPV yang positif mengindikasikan bahwa usaha layak di laksanakan. Hasil perhitungan diperoleh BC Ratio dengan diskon faktor $15 \%$ sebesar 3,880.Nilai IRR yang diperoleh sebesar 50,05\%.Artinya nilai sekarang investasi dan nilai sekarang penerimaan bersih akan sama besar pada tingkat bunga $50,05 \%$. Hasil perhitungan tersebut menunjukan tingkat laba usaha lebih besar daripada tingkat bunga kredit bank komersial yang berlaku sebesar $24 \%$. Dengan demikian usaha peternakan sapi perah dikelompok Ramulu Sangkor dinyatakan layak untuk dijalankan.Hasil perhitungan nilai ROI sebesar $41,82 \%$. 
Nilai ROI tersebut lebih besar daripada tingkat bunga deposito bank yang berlakusebesar 24\%. Artinya Usaha peternakan kelompok Ramulu Sangkor layak beroperasi.

Tabel 1. Biaya Produksi, Penerimaan, Keuntungan dan Kriteria Investasi Kelompok Sapi Perah di Kota Tomohon.

\begin{tabular}{|c|c|c|c|c|}
\hline Uraian & \multicolumn{4}{|c|}{ Tahun } \\
\hline Biaya Produksi & 2012 & 2013 & 2014 & rata-rata \\
\hline Susu & 167.493 .750 & 167.293 .750 & 176.993 .750 & 170.593.750 \\
\hline Es krim & 45.194.166 & 103.477.616 & 226.315.116 & 124.995.632 \\
\hline Kripik Susu & 140.832 .500 & 508.907 .500 & 625.246 .500 & 424.995 .500 \\
\hline Biogas & - & 3.044.250 & - & 1.014750 \\
\hline Total Biaya Produksi & 353.520.416 & 782.723.116 & 1.028.555.366 & 721.599.633 \\
\hline \multicolumn{5}{|l|}{ Penerimaan } \\
\hline Susu & 81.700 .000 & 122.045.000 & 144.552.000 & 9.943.233. \\
\hline Es krim & 95.100 .000 & 396.250.000 & 951.000 .000 & 480.783.333 \\
\hline Kripik Susu & 95.100 .000 & 396.250.000 & 570.600 .000 & 353.983.333 \\
\hline Biogas & - & 495.000 & 561.000 & 352.000 \\
\hline Total Penerimaan & 271.900 .000 & 915.040 .000 & 1.666.713.000 & 951.217 .667 \\
\hline \multicolumn{5}{|l|}{ Keuntungan } \\
\hline Susu & -135.793 .750 & -45.248 .750 & -32.441 .750 & $\begin{array}{r}-71.16 \\
1.416 \\
\end{array}$ \\
\hline Es krim & 49.905.834 & 292.772.784 & 724.684.884 & 355.787.834 \\
\hline Kripik Susu & -45.732 .500 & -112.657 .500 & -54.646 .500 & -71.012 .166 \\
\hline Biogas & - & -2.549 .250 & 561.000 & -662.750 \\
\hline Total Keuntungan & -131620416 & 132.317.284 & 638.157.634 & 229.618.034 \\
\hline NPV & \multicolumn{4}{|l|}{\begin{tabular}{|l|l}
448.929 .526 \\
\end{tabular}} \\
\hline BC Ratio & \multicolumn{4}{|l|}{2,880} \\
\hline IRR & \multicolumn{4}{|l|}{50,05} \\
\hline ROI & \multicolumn{4}{|l|}{ 41,82 } \\
\hline
\end{tabular}

\section{KESIMPULAN}

Berdasarkan hasil penelitian dapat disimpulkan bahwa :

1. Usaha peternakan sapi perah kelompok Ramulu Sangkor di Kota Tomohon dengan jumlah 10 ekor secara finansial layak untuk dijalankan, hal ini dapat dilihat dari analisis kriteria investasi yang menunjukan bahwa $\mathrm{NPV}=\mathrm{Rp} .448 .929 .526>0, \quad \mathrm{BC}$ Ratio $=2,880>1, \mathrm{IRR}=50,05>$ Tingkat bunga yang berlaku, ROI=41,82 > Suku bunga bank.

2. Usaha peternakan sapi perah kelompok Ramulu Sangkor memiliki keuntungan sehingga usaha peternakan itu layak 
untuk dijalankan. Dimana untuk 10 ekor sapi perah memiliki keuntungan sebesar Rp.688.854.102 selama 3 tahun.

\section{DAFTAR PUSTAKA}

Arifin, B. 2004. Analisis Ekonomi

Pertanian Indonesia (An Analysis on Indonesian Agricultural Economics). Jakarta: Penerbit Buku KOMPAS. 304 pages. ISBN 979-709-134.

Alfiyan, M. 2008. Persepsi peternak terhadap program kelayakan pengembangan peternakan sapi perah di luar wilayah lembang.Skripsi program studi sosial ekonomi peternakan Institut Pertanian Bogor. Bogor.

Badan Pusat Statistik SULUT, 2013. RataRata Konsumsi Kalori dan Protein Per Kapita Sehari menurut Kelompok Makanan. http://sulut.bps.go.id. Manado. Diunduh 12 November 2013.

Departemen Pertanian RI, 2013. Kawasan Komoditas Unggulan. Sekretariat Jenderal Kementerian Pertanian Biro

Perencanaan.http://perencanaan.setj en.deptan.go.id. Diunduh 26 november 2013.

Dinas Pertanian dan Peternakan SULUT, 2013.Data Kelompok Sapi Perah di Provinsi Sulawesi Utara.Kalasey.

Krisna, R. dan E. Manshur, 2006. Tingkat Pemilikan Sapi (Skala Usaha) Peternakan Dan Hubungannya Dengan Keuntungan Usaha TaniTernakPadaKelompokTaniTern akSapiPerah Di DesaTajurHalang

Kadariah. 2001. Evaluasi Preoyek Analisis Ekonomis. Lembaga Penerbit Fakultas Ekonomi Universitas Indonesia, Jakarta

Priyono, 2008.Studi Keterkaitan Antara Ikatan Sosial Dengan pendapatan dan Efisiensi Usaha Ternak Sapi Potong Di Kabupaten
Banjarnegara.Skripsi.Fakultas Peternakan Universitas Soedirman. Purwokerto.

Riyanto, B. 2001. Dasar-dasar pembelanjaan Perusahaan. Penerbit BPFE, Yogyakarta 